\title{
Theoretical Framework for Corporate Disclosure Research
}

\author{
Dr. Narendra Sharma (Corresponding author) \\ Assistant Professor of Accounting, Elizabeth City State University \\ 1704 Weeksville Road, Elizabeth City, NC 27909 \\ Tel: 1-252-335-3186_E-mail: nsharma@mail.ecsu.edu
}

Received: Feb. 3, $2013 \quad$ Accepted: April 12, $2013 \quad$ Published: June 1, 2013

doi:10.5296/ajfa.v5i1.3210ＵRL: http://dx.doi.org/10.5296/ajfa.v5i1.3210

\begin{abstract}
This paper discusses the theoretical frameworks for a corporate disclosure research. It introduces the general nature and types of theories. It then compares and contrasts views of what constitutes a theory. There was no single view of theory. There were differences in approaches and interpretations. The conception of a theory and its relationship with research is discussed in light of both quantitative and qualitative methods of research and their contribution to theory are assessed. Both quantitative and qualitative methods contributed to theory building, theory testing, and substantiating, or refuting their propositions. Although, positive accounting theory had grown as one of the most significant accounting research program, the broad theories of accounting included interpretive and normative theories as well. The review of the literature revealed that there were a number of theories associated with corporate accounting and disclosure, amongst them were agency theory, signaling theory, the accountability theory, legitimacy theory, contingency theory, stakeholder theory, and resource dependency theory.
\end{abstract}

Keywords: Corporate disclosure; Theoretical framework; Normative accounting theory; Positive accounting theory; Agency theory; Signaling theory 


\section{Introduction}

This paper discusses the theoretical frameworks for a corporate disclosure research. It introduces the nature and types of theories in general. It then compares and contrasts views of what constitutes a theory including the views prevalent in the field of accounting research. The distinction between a theory and related concepts like hypothesis, paradigm, model and concepts is made. The conception of a theory and its relationship with research is discussed. A quantitative and qualitative method of research and their contribution to theory is assessed. Theories used in accounting research are traced, and the most commonly used theory was identified depending upon the type of corporate disclosure study envisioned. The contributions, controversies, and gaps in the identified theory was discussed and analyzed.

There are several conceptions of theory; each of them differed in terms of their nature and scope. Dominant views of theory in the field of accounting were interpretive, normative and positive. Researchers were using qualitative or quantitative methods based on the paradigms of their research and ontological or epistemological assumptions.

Stam (2010) defined theory as a 'systematic representation' of a valid problem expressed, as far as possible, mathematically, in the natural sciences or logically in the life and social sciences. The aims of systematic representations are to develop explanations of a problem, describe the delineating features of a phenomenon, and provide predictions (Stam, 2010). Stam (2007) explained that there were three significant opinions of theory in the twentieth century. They were reductionism, instrumentalism, and realism. The reductionism viewpoint was the ability of a theory to be reduced to observables. The instrumentalism viewpoint used theory as instruments to do things and the realism considered theory as statements about phenomena that actually existed in the world. Stam (2007) explained that observations, gradually, got separated from theory as 'deductive-nomonological' framework came into existence in the context of behaviorist's interpretation of the theory. However, the development of inferential statistics encouraged broader use of theoretical models and that led to the demise of behaviorism (Stam, 2007).

An uncertainty is evident in what constitutes a theory (Gelso, 2006). A common misunderstanding was with broad un-testable philosophies of human life. These are comprehensive theories, which are never disproved totally, although some aspects of them could be disconfirmed (Gelso, 2006). Generally, a theory was a statement of the hypothesized, assumed, or even factual relationship amongst variables with the theoretical proposition explaining the relationships between constructs that can ultimately become an uncontested fact. But, the eventual quality of a theory depends upon its ability to explain why the variables are related and what causes that expected relationship (Gelso, 2006).

Harlow (2009) believed that the word theory had several meanings. For natural scientists, theory suggested a decisive law or a system of law, and for others, it was a construct or a set of constructs for comprehending a phenomenon. Harlow (2009) proposed a case study method of research using inductive or deductive reasoning to test and develop a theory.

Wacker (2008) defined a theory as "an explained set of conceptual relationships” (p.5). A 
theory must be able to explain the frequently asked questions of a conceptual relationship in the order who, what, when, where, and how. Followed by what, would, should, or could question (Wacker, 2008). These questions provided the four fundamental properties of the definition of a theory. Wacker (1998) identified the four properties as: (a) definitions of variables; (b) the domain of theory application; (c) relationship between variables; and (d) predictions. Wacker (1998) further elaborated that a theory will be construed as 'good' only if it explains the conceptual relationships in such way that it can be used for empirical testing and possesses certain restrictions on the four properties just described. Therefore, the normal array of virtues of a theory is that it should be unique, with fewer assumptions, conservative, generalizable, internally consistent, generate more research in new areas, at an appropriate level of abstractions, and empirically risky enough to be refuted (Wacker, 1998).

Corley and Gioia (2011) defined a theory as a statement of concepts showing interrelations between such concepts that provided the explanations about how and why such a relationship existed. There were two identifiers of theoretical contributions: originality and utility. Hence, the ability to generate original ideas to explain a phenomena thereby creating knowledge, which has a practical utility, is making theoretical contribution (Corley \& Gioia, 2011).

Miller and Bahnson (2010) explained that the purpose of accounting theories was to ensure better accounting practice. In pursuit of this, a normative accounting framework was used to search for practices that should be used instead of describing practices that are actually used. Hence, normative accounting theory was prescriptive in nature. Miller and Bahnson (2010) argued that accounting and reporting should be prescriptive because pragmatic considerations contaminate them rather than improve them. Hence, it is built around what should be done without any regard to what actually is being practiced (Miller \& Bahnson, 2010).

Jeanjean and Ramirez (2009) traced the changing shift between normative theories and the professional world of accounting and found two categories of normative accounting research. One was designed for policy prescription, and the other was for framework building. Two approaches were identified as inductive and deductive. The deductive approach used theory building based on observation of practices. However, inductive approach started with an abstract idea from accounting knowledge so that rules could be generated to guide the practice of accounting. Therefore, the natural outcome of normative theory was framing the standards of practice, assisting the profession in designing solutions to the problems encountered by them (Jeanjean \& Ramirez, 2009).

Collin, Tagesson, Anderson, Cato, and Hansson (2009) explained that there were two theories that explained accounting choices. Based on the scientific literature, positive accounting theory (PAT) and institutional theory (IT) offered explanations and predictions of accounting choices. PAT provided the set of predictions regarding accounting choices affecting the wealth of stakeholders and emphasized on the existence of agency problems. Hence, Collin et al. (2009) considered PAT as an appropriate theory in explaining accounting choices of companies that had agency problems. IT, on the other hand, was used to explain accounting 
choices based on institutional pressures the organizations were exposed, be it normative, coercive, or mimetic. The methodology used tended to be more case studies based and ideographic (Collin et al., 2009).

Theories renowned in accounting are mostly those adapted from other disciplines (Malmi \& Granlund, 2009). Malmi and Granlund (2009) argued that theories in management accounting research should endeavor to suggest explanations that were useful to managers, organizations, and society at large.

Yi, Davey, and Eggleton (2011) suggested a comprehensive theoretical framework using a multi-theory approach including agency theory, stakeholder theory, signaling theory, and legitimacy theory in the framework to study disclosure decisions. Agency theory was based on the concept of separation of ownership and management creating a principal-agent relationship. Disclosures were considered part of the monitoring package to reduce the information asymmetry and agency problems with their resulting costs. Yi et al. (2011) described that stakeholder theory extended the shareholder point of view to include several stakeholders in a relationship between them and the organization. There were two sources of accountability under the stakeholder theory: ethical responsibilities, and managerial responsibilities. The proponents of signaling theory suggested that information asymmetry could be reduced by sending signals to interested parties (Yi et al., 2011). Another theory, legitimacy theory, as suggested by Yi et al. (2011) explained the relationship between the organization and society at large in terms of a "social contract".

Chen and Roberts (2010) described the theoretical considerations for a social and environmental accounting research. They suggested that using legitimacy theory, institutional theory, resource dependency theory, and stakeholder's theory could make appropriate interpretations of business activities. However, the choice of the theory would depend on the focus of the study. The theories were believed to share the similar ontological views and were largely considered as system-oriented theories (Chen \& Roberts, 2010).

Kakkuri-Knuuttila, Lukka, and Kuorikoski (2008) analyzed the interpretive research in management accounting. Management accounting researchers were found to apply qualitative methodology to interpret case studies to offer insights regarding the practice of accounting in different organizational contexts. Accordingly, the conceptions of a theory in this format of research were "making sense" of human actions and describe how the research subjects interpreted the context within the framework of subjectivism (Kakkuri-Knuuttila et al, 2008).

Baker (2011) opined that accounting research was fragmented into paradigmatic lines, and such fragmentation was a recent phenomenon. There were very few divisions in accounting research till the 1970s, and Baker (2011) stated that, by the end of 1980s, there was a major shift in accounting research from a normative framework to an empirical and positivist research. The positivist research was based on a scientific model, in which hypotheses were proposed, numerical data collected, and data analysis was carried out to test the hypotheses and make inferences using mostly quantitative methods (Baker, 2011). 
With this background, the rest of the paper is devoted to reviewing the existing literature and making recommendations for theoretical frameworks for a disclosure research and finally some conclusions are drawn based on the review of relevant literature.

\section{Review of Literature}

There is confusion about what constitutes a theory (Gelso, 2006) as the word theory has several meanings (Harlow, 2009). It is a 'systematic representation' of a valid problem expressed, as far as possible, mathematically in the natural sciences or logically in the life and social sciences (Stam, 2010). For natural scientists, it was a decisive law or a system of law, and for social scientists, it was a construct or a set of constructs for comprehending a phenomena (Harlow, 2009). In social sciences, a common misunderstanding about theory was with broad un-testable philosophies of human life, assertions of faith, and at times propositions that were not made with testability considerations (Gelso, 2006). These overarching theories were not scientifically useful, as they could not generate research that could be tested for validity (Gelso, 2006). Wacker (2008) defined a theory as "an explained set of conceptual relationships” (p.5). Corley and Gioia (2011) echoed similar opinion when they explained the theory as statement of concepts showing interrelations between those concepts that provided the explanations about how and why such a phenomenon occurred. Another is the deductive-nomonological viewpoint, in which theory is considered as statements that have a precise relationship to the events requiring explanation (Stam, 2007). In accounting, theory is a framework that ensures better accounting practice, like the conceptual framework (Miller \& Bahnson, 2010). Hence, it is built around what should be done without any regard to what actually is being practiced (Miller \& Bahnson, 2010). In that sense one of the outcomes of a theory in accounting is framing the standards of practice, and assisting the profession in designing solutions to the problems encountered by them (Jeanjean \& Ramirez, 2009) and provide explanations and predictions of accounting choices (Collin et al., 2009). In management accounting, theories suggest explanations that are useful to managers, organizations, and the society at large (Malmi \& Granlund, 2009). The conceptions of a theory in this format were "making sense" of human actions and describing how the research subjects interpreted the context within the framework (Kakkuri-Knuuttila et al., 2008). Therefore, a theory is ultimately tested and becomes an uncontested fact (Gelso, 2006) but retains the characteristics of refutability (Wacker, 1998).

Another way of looking at a theory was by finding out what constitutes a good theory. To that direction, Wacker (1998) identified four properties of a good theory; they were (a) definitions of variables; (b) the domain of theory application; (c) relationship between variables; and (d) predictions. Hence, a theory is a statement that defines the variables, outlines the domain it can be used, explains the relationships, and provides predictions about the occurrences of those variables (Wacker, 1998). It also needs to be original in conception or improving the abstraction level, and needs to have utility in explaining or predicting the relationships (Corley \& Gioia, 2011).

There were several views of theory in accounting, but there were three views that were prominent in the literature: interpretive view, normative view, and positive view. 
Interpretative views were reflective in field studies, case studies, and action research mostly fitting into the qualitative strand of research. Management accounting researchers evidently preferred qualitative research (Parker, 2012). Case studies featured in these researches, typically addressed the "why" question, and investigated a phenomena in actual practice involving non-quantifiable variables in which context was important to be studied (Cooper \& Morgan, 2008). Case studies are popularly used for verifying or developing theoretical frameworks using explanations, strengths, and weaknesses identified either by inductive or deductive reasoning (Harlow, 2009). Action research is another qualitative research methodology that creates rich data by an involved participation as an insider in an organization with a clear intention to achieve a chosen result (Ansari \& Bell, 2009). The researcher adds to the body of existing theoretical knowledge with a heuristic value because the action researcher not only observes what is happening in a real world but also participates in action to achieve the desired goal (Ansari \& Bell, 2009). The legitimate problem-solving objective of action research deals with the "crisis of relevance" in accounting research and provides real experiences in a collaborative exercise. It seeks solutions to practical problems and generates new knowledge with the active involvement of a researcher and client working on a real-life project (Giuliani, 2009).

Another view of accounting theory was the normative view. Jeanjean and Ramirez (2009) traced two categories of normative accounting research. One was designed for policy prescription, and the other was for framework building. The natural outcome of normative theory was framing the standards of practice, assisting the profession in designing solutions to the problems encountered by them (Jeanjean \& Ramirez, 2009; Miller \& Bahnson, 2010). The purpose of a theory in accounting is to ensure better accounting practice (Miller \& Bahnson, 2010). In pursuit of this, Miller and Bahnson (2010) proposed that a normative accounting framework was to be used to search for practices that should be used instead of describing practices that are actually used. The accounting and reporting should be prescriptive because pragmatic considerations contaminate them rather than improve them; hence, it is built around what should be done without any regard to what actually is being practiced (Miller \& Bahnson, 2010).

The third view was a positivist view of accounting theory. Baker (2011) informed that, by the end of 1980s, there was a major shift in accounting research from a normative framework to an empirical and positivist research. Ashton et al. (2009) expressed the same view, as they found relatively little research that could be categorized as normative covering the study period between the years 2001 and 2007. Bisman (2010) explained that there was no doubt about the growth in accounting research using interpretive approaches but positive accounting theory based on objectivist ontology had dominated the literature. Ashton et al. (2009) explained that there was increased popularity of positivist approaches to research. The positivist approach is the scientific approach that is appropriately identifies, explains and predicts accounting phenomena. It was founded on the ontological view that "the reality of accounting can be discovered by the use" (Bisman, 2010, p. 6). Based on their literature review, Collin et al. (2009) elucidated that positive accounting theory (PAT) was one of the theories that offered explanations and predictions about accounting choices affecting the 
wealth of stakeholders based on the concept of agency problems. Positive accounting theory posits that agency costs will vary from company to company depending upon political and social influences (Broberg, Tagesson, \& Collin, 2010).

There were other theories used in accounting and especially disclosure studies. Yi et al. (2011) described stakeholder theory as extending the shareholder point of view to include several stakeholders in a relationship between them and the organization. Signaling theory suggested that information asymmetry could be reduced by sending signals to interested parties and legitimacy theory as explained by Yi et al. (2011) was based on a "social contract" between the organization and society at large. Chen and Roberts (2010) described the theoretical framework for a social and environmental accounting and disclosure research using legitimacy theory, institutional theory, resource dependency theory, and stakeholder's theory. Aston et al. (2009) found many management accounting researchers were using contingency theory.

There are concepts related to theory like paradigms, hypothesis, model and concept. Morgan (2007) described four perspectives of paradigms. The first way of looking at a paradigm was as worldviews; researchers may have based on their experiences, beliefs, morals, values, and a set of assumptions about how the world works that may impact every aspect of their research (Morgan, 2007). The second version of a paradigm is to consider them as epistemological stances like realism and constructivism within the philosophy of knowledge and ways of creating that knowledge (Morgan, 2007). The third view of paradigm is more specific and deals it as the "shared beliefs within a community of researchers" (Morgan, 2007, p. 53) about the questions and procedures of answering those questions. The fourth and the last version of the paradigm are considered as the set of rules that can be used for generalizations, models, values, and examples of solutions for similar researches done in the given field (Jeanjean \& Ramirez, 2009). Taneja, Taneja, and Gupta (2011) explained that such perspectives help researchers to take philosophical examinations of phenomena's ontological and epistemological assumptions. Model, on the other hand, is a semantic conception of a theory. Morgan (2007) opined that a theoretical model would comprise of four features: variables or phenomena of interests, laws of interaction of these variables, boundaries of the theory, and system states. Gelso (2006) explained that theories offered propositions, and hypotheses were consequential to such propositions. Hypotheses are proposed relationship between variables (Perkins, 2010) that are tested empirically in inferential research to draw inferences about the unobserved from the observed phenomena (Gelson, 2006). Concepts are the primary elements of theory and a phenomenon that can be observed. However, phenomena, which cannot be observed, and hence must be inferred, are constructs. They become concepts from constructs when they are derived or used in a particular theory. These could be physical phenomena (concepts) or abstract, theoretical constructs (Kimberlin \& Winterstein, 2008).

Research, in accounting, suggests solutions to practical problems, and investigates relationships between phenomena to contribute to the body of knowledge. Research needs to provide answers to the questions of what, why, when, how, where, and who about a phenomena (Ellis \& Levy, 2008). The goal is reflected in the overall intent or objective of 
the research, and the research questions or hypotheses are specific questions the researcher intends to find answers (Ellis \& Levy, 2008). Social researchers need to forsake the idea of building a grand theory mirroring the natural science rather concentrate on small hypotheses closer to social actuality (Andersen \& Kragh, 2010). Qualitative research could be used for theory building excise or theory testing (Andersen \& Kragh, 2010) by seeking explanations and building interrelationships. A case study involving a theory except in case of descriptive case studies (Harlow, 2009) provides the map for theory building. They could be used either to test a particular theory, develop a new theory, or a combination of both. Research will begin with a review of literature (Ellis \& Levy, 2008; Harlow, 2009) that could be used to identify existing theoretical expositions of the topic. Developing a theory is a circular process of testing the idea against data, reframing the idea, and retesting until trustworthy conclusions can be reached (Harlow, 2009). Researchers use theory to make predictions and test these predictions empirically to emphasize the strength and weaknesses of different theories (Colin et al., 2009). Colquitt and Zapata-Phelan (2007) examined the two ways an empirical research can contribute to theory: (a) to test a theory in the spirit that a theory, which was not mortally endangered, would not remain alive for long; (b) building a theory usually following inductive reasoning. Ketchen and Hult (2011) suggested three tools to build a theory. The first metric of quality theorizing was that theory had to be interesting to capture attention of others so that it could be built upon by other researchers. The second metric was generalizability, and the third was accuracy and simplicity. Tacq (2011) described that quantitative research used post positivistic approach reducing the phenomena to variables and hypotheses using measurements, experiments and surveys to collect data and carried out statistical analysis with an emphasis on testing of theories. On the other hand, qualitative methods primarily used constructivist perspective in developing a theory or pattern. Zahra and Newey (2009) conceptualized that theory-building research could impact theories by adding or polishing explanatory and predictive abilities to address focal issues of a theory. Richardson (2012) commented research could contribute to accounting practice immensely without actually contributing to the original theory but simply adding to the body of knowledge by assessment of the anomalies or evaluate boundaries thereby becoming producers of theoretical insights.

\section{Recommendations and Conclusions}

Collin et al. (2009) opined that positive accounting theory offered explanations and predictions of accounting choices affecting the wealth of stakeholders and emphasized on the existence of agency problems. Positive accounting theory posits that agency costs will vary from company to company (Broberg, Tagesson, \& Collin, 2010). Based on these premises and others, an agency theory has evolved. Yi et al. (2011) explained that agency theory was based on the concept of separation of ownership and management creating a principal-agent relationship. Christopher (2010) reviewed the extant literature through a theory building approach and traced opinions that agency theory provided the structural platform to determine contractual relationship and obligations between the major parties in an organization. Bauwhede and Willekens (2008) used agency theory to study the disclosure on corporate governance in the European Union and concluded that their results supported 
the theoretical argument about companies disclosing corporate governance information in order to reduce information asymmetry and the agency costs. Henry (2010) proposed that corporate governance disclosure would reduce the agency conflicts and thus results into a reduction of agency costs. Kelton and Yang (2008) used the agency theory to study the impact of corporate governance on Internet financial reporting. Kent and Stewart (2008) based their study on the belief that well-governed firms would increase their disclosures as a means of mitigating agency problems existing between the management and shareholders. Taylor, Tower, van der Zahn, and Neilson (2008) studied the financial instrument disclosure practices of Australian companies using agency theory as their conceptual framework. Tsamenyi, Enninful-Adu, and Onumah (2007) used the agency theory to study the disclosure and corporate governance in Ghana. Chen, Elder, and Hsieh (2007) examined the relationship between corporate governance and earnings management in the Taiwanese market using agency theory. Hence, agency theory under a positive accounting outlook, may provide a sound theoretical basis for studying disclosure decisions made by corporations.

However, there are some areas of controversies and unanswered questions. Agency theory posits a positive correlation between profitability and disclosure. The same, positive and significant, a relation between profitability and disclosure was found (Aerts, Cormier, \& Magnan, 2007; Akhtaruddin, Hossain, Hossain, \& Yao, 2009; Li, Pike, \& Haniffa, 2008). On the other hand, Ho and Taylor (2007) reported a negative relationship between disclosure and profitability. Furthermore, an insignificant impact of profitability on the levels of disclosure was found (Aljifri, 2008; Ferrer \& Ferrer, 2011; Mia \& Al-Mamun, 2011). Hence, there are three different perspectives using the same theory. Another area of controversy is the relationship between leverage and disclosure. Agency theory proposes higher incentives to disclose information by leveraged firms to reduce agency costs (Kang \& Gray, 2011). However, higher leveraged firms disclosed less information as compared to other firms (Aerts et al., 2007; Cormier, Aerts, Ledoux, \& Magnan, 2009). On the other hand, leverage did not have any significant impact on the levels of disclosure (Akhtaruddin et al., 2009; Aljifri, 2008; Ho \& Taylor, 2007; Mia \& Al-Mamun, 2011). Although, there are some controversies and unanswered questions related to agency theory, it provides the structural platform and theoretical framework for disclosure decisions (Kelton \& Yang, 2008).

Most of the theories prevalent in accounting were borrowed theories from other disciplines, and hence there was a need for efforts to theorize in accounting contexts. Qualitative and quantitative research could both make contributions to theory either in building it, testing it or improving it. The choice of methods would depend upon the ontological and epistemological assumptions involved in research. There were three views of accounting theory, interpretive, normative, and positive. Accountants need prescription in many things they do and hence normative accounting theory would serve that purpose. Management accountants and other emerging fields in accounting could continue to use interpretive view of accounting and engage in qualitative research using contingency theory. Financial accounting and other allied areas could continue to use quantitative methods in a positive accounting framework. Specialty fields like social responsibility accounting, intellectual 
capital, and environmental disclosure studies fit well into the legitimacy theory and stakeholder's theory. Many disclosure studies especially mandatory disclosure studies, and research in auditing, and taxation would benefit from using the institutional theory. Generally, agency theory provides the required framework to evaluate accounting choices and disclosure decisions in market-based studies.

\section{References}

Aerts, W., Cormier, D., \& Magnan, M. (2007). The association between web-based corporate performance disclosure and financial analyst behaviour under different governance regimes. Corporate Governance: An International Review, 15(6), 1301-1329. http://dx.doi.org/10.1111/j.1467-8683.2007.00648.x

Akhtaruddin, M., Hossain, M., Hossain, M., \& Yao, L. (2009). Corporate governance and voluntary disclosure in corporate annual reports of Malaysian listed firms. Journal of Applied Management Accounting Research, 7(1), 1-19. Retrieved from http://www.cmawebline.org

Aljifri,K. (2008). Annual report disclosure in a developing country: The case of the UAE. Advances in Accounting, 24(1), 93-100. http://dx.doi.org/10.1016/j.adiac.2008.05.001

Andersen, P. H., \& Kragh, H. (2010). Sense and sensibility: Two approaches for using existing theory in theory-building qualitative research. Industrial Marketing Management, 39 (1), 49-55. http://dx.doi.org/10.1016/j.indmarman.2009.02.008

Ansari, S., \& Bell, J. (2009). Five easy pieces: A case study of cost management as organizational change. Journal of Accounting \& Organizational Change, 5(2), 139-167. http://dx.doi.org/10.1108/18325910910963418

Ashton, D., Beattie, V., Broadbent, J., Brooks, C., Draper, P., Ezzamel, M., . . . Stark, A. (2009). British research in accounting and finance (2001-2007): The 2008 research assessment exercise. The British Accounting Review, 41(4), 199-207. http://dx.doi.org/10.1016/j.bar.2009.10.003

Baker, C. R. (2011). A genealogical history of positivist and critical accounting research. Accounting History, 16(2), 207-221. http://dx.doi.org/10.1177/1032373210396335

Bauwhede, H. V., \& Willekens, M. (2008). Disclosure on corporate governance in the European Union. Corporate Governance: An International Review, 16(2), 101-115. http://dx.doi.org/10.1111/j.1467-8683.2008.00671.x

Bisman, J. (2010). Postpositivism and accounting research: A (personal) primer on critical realism. Australasian Accounting Business \& Finance Journal, 4(4), 3-25. Retrieved from http://ro.uow.edu.au/aabfj/

Broberg, P., Tagesson, T., \& Collin, S. (2010). What explains variation in voluntary disclosure? A study of the annual reports of corporations listed on the Stockholm stock exchange. Journal of Management \& Governance, 14(4), 351-377. http://dx.doi.org/10.1007/s10997-009-9104-y 
Chen, J., \& Roberts, R. (2010). Toward a more coherent understanding of the organization-society relationship: A theoretical consideration for social and environmental accounting research. Journal of Business Ethics, 97(4), 651-665. http://dx.doi.org/10.1007/s10551-010-0531-0

Chen, K. Y., Elder, R. J., \& Hsieh, Y. (2007). Corporate governance and earnings management: The implications of corporate governance best-practice principles for Taiwanese listed companies. Journal of Contemporary Accounting \& Economics, 3(2), 73-105. http://dx.doi.org/10.1016/S1815-5669(10)70024-2

Christopher, J. (2010). Corporate governance-A multi-theoretical approach to recognizing the wider influencing forces impacting on organizations. Critical Perspectives on Accounting, 21(8), 683-695. http://dx.doi.org/10.1016/j.cpa.2010.05.002

Collin, S. Y., Tagesson, T., Andersson, A., Cato, J., \& Hansson, K. (2009). Explaining the choice of accounting standards in municipal corporations: Positive accounting theory and institutional theory as competitive or concurrent theories. Critical Perspectives on Accounting, 20 (2), 141-174. http://dx.doi.org/10.1016/j.cpa.2008.09.003

Colquitt, J. A., \& Zapata-Phelan, C. P. (2007). Trends in theory building and theory testing: A five- decade study of The Academy of Management Journal. Academy of Management Journal, 50(6), 1281-1303. http://dx.doi.org/10.5465/AMJ.2007.28165855

Cooper, D. J. \& Morgan, W. (2008). Case study research in accounting. Accounting Horizons, 22 (2), 159-178. http://dx.doi.org/10.2308/acch.2008.22.2.159

Corley, K. G., \& Gioia, D. A. (2011). Building theory about theory building: What constitutes a theoretical contribution? Academy of Management Review, 36(1), 12-32. http://dx.doi.org/10.5465/AMR.2011.55662499

Cormier, D., Aerts, W., Ledoux, M. J. \& Magnan, M. (2009). Attributes of social and human capital disclosure and information asymmetry between managers and investors. Canadian Journal of Administrative Sciences, 26(1), 71-88. http://dx.doi.org/10.1002/cjas.89

Ellis, T. \& Levy, Y. (2008). Framework of problem-based research: A guide for novice researchers on the development of a research-worthy problem. Informing Science: the International Journal of an Emerging Transdiscipline, 11, 17-33. Retrieved from http://inform.nu/Articles/Vol11/ISJv11p017-033Ellis486.pdf

Ferrer, R. C., \& Ferrer, G. J. (2011). The relationship between profitability and the level of compliance to the international financial reporting standards (IFRS): An empirical investigation on publicly listed corporations in the Philippines. Academy of Accounting and Financial Studies Journal, 15(4), 61-82. $\quad$ Retrieved from http://www.alliedacademies.org/public/AffiliateAcademies/aafs.aspx

Gelso, C. (2006). Applying theories to research: The interplay of theory and research in science. In Leong, F.T., \& Austin, J.T. (Eds.). The Psychology Research Handbook, 2, 456-465). Thousand Oaks, CA: Sage Publications. doi:10.4135/978-1-41297 
Giuliani, M. (2009). Intellectual capital under the temporal lens. Journal of Intellectual Capital, 10(2), 246-259. http://dx.doi.org/10.1108/14691930910952641

Harlow, E. (2009). Contribution, theoretical. In Mills, A. J., Durepos, G., \& Wiebe, E. (Eds.). Encyclopedia of Case Study Research, 237- 239. Thousand Oaks, CA: Sage Publications. Retrieved from http://www.sage-ereference.com

Henry, D. (2010). Agency costs, ownership structure and corporate governance compliance: A private contracting perspective. Pacific-Basin Finance Journal, 18(1), 24-46. http://dx.doi.org/10.1016/j.pacfin.2009.05.004

Ho, L. J., \& Taylor, M. E. (2007). An empirical analysis of triple bottom-line reporting and its determinants: Evidence from the United States and Japan. Journal of International Financial $\begin{array}{lll}\text { Management accounting, 18(2), } & \text { 123-150. }\end{array}$ http://dx.doi.org/10.1111/j.1467-646X.2007.01010.x

Jeanjean, T., \& Ramirez, C. (2009). Back to the origins of positive theories: A contribution to an analysis of paradigm changes in accounting research. Accounting in Europe, 6(1), 107-126. http://dx.doi.org/10.1080/17449480902896510

Kakkuri-Knuuttila, M. L., Lukka, K. \& Kuorikoski, J. (2008). Straddling between paradigms: A naturalistic philosophical study on interpretive research in management accounting. Accounting, Organizations and Society, 33 (2-3), 267-91. http://dx.doi.org/10.1016/j.aos.2006.12.003

Kang, H. H., \& Gray, S. J. (2011). Reporting intangible assets: Voluntary disclosure practices of top emerging market companies. The International Journal of Accounting, 46(4), 402-423. http://dx.doi.org/10.1016/j.intacc.2011.09.007

Kelton, A. S., \& Yang, Y. (2008). The impact of corporate governance on internet financial reporting. Journal of Accounting and Public Policy, 27(1), 62-87. http://dx.doi.org/10.1016/j.jaccpubpol.2007.11.001

Kent, P., \& Stewart, J. (2008). Corporate governance and disclosures on the transition to international financial reporting standards. Accounting \& Finance, 48(4), 649-671. http://dx.doi.org/10.1111/j.1467-629X.2007.00257.x

Ketchen, Jr., D. J., \& Hult, G. T. M. (2011), Building theory about supply chain management: Some tools from the organizational sciences. Journal of Supply Chain Management, 47(2), 12-18. http://dx.doi.org/10.1111/j.1745-493X.2011.03220.x

Kimberlin, C. L. \& Winterstein, A. (2008). Validity and reliability of measurement instruments used in research. American Journal of Health-System Pharmacy, 65, 2276-2284. doi: 10.2146/ajhp07036

Li, J., Pike, R., \& Haniffa, R. (2008). Intellectual capital disclosure and corporate governance structure in UK firms. Accounting and Business Research, 38(2), 137-144,146,149,151-159. http://dx.doi.org/10.1080/00014788.2008.9663326 
Malmi, T., \& Granlund, M. (2009). In search of management accounting theory. European Accounting Review, 18(3), 597-620. http://dx.doi.org/10.1080/09638180902863779

Mia, P., \& Al- Mamun, A. (2011). Corporate social disclosure during the global financial crisis. International Journal of Economics and Finance, 3(6), 174-187. http://dx.doi.org/10.5539/ijef.v3n6p174

Miller, P. B. W., \& Bahnson, P. R. (2010). Continuing the normative dialog: Illuminating the asset/liability theory. Accounting Horizons, 24(3), 419-440. http://dx.doi.org/10.2308/acch.2010.24.3.419

Morgan, D. L. (2007). Paradigms lost and pragmatism regained: Methodological implications of combining qualitative and quantitative methods. Journal of Mixed Methods Research, 1 (1), 48-76. http://dx.doi.org/10.1177/2345678906292462

Parker, L. D. (2012). Qualitative management accounting research: Assessing deliverables and relevance. Critical Perspectives on Accounting, 23, 54-70. http://dx.doi.org/10.1016/j.cpa.2011.06.002

Perkins, W. C. (2010). An introduction to the economic method. American Economist, 55(1), 73-83. Retrieved from http://www.omicrondeltaepsilon.org/americaneconomist.html

Richardson, A. J. (2012). Paradigms, theory and management accounting practice: A comment on Parker (forthcoming) "Qualitative management accounting research: Assessing deliverables and relevance". Critical Perspectives on Accounting, 23, 83-88. http://dx.doi.org/10.1016/j.cpa.2011.05.003

Stam, H. (2007). Theoretical psychology. In Pawlik, K., \& Rosenzweig, M. R. (Eds.). The International Handbook of Psychology, 552-570. Thousand Oaks, CA: SAGE Publications.

Stam, H. (2010). Theory. In Salkind, N. J. (Eds.). Encyclopedia of Research Design, 1499-1503. Thousand Oaks, CA: SAGE Publications. Retrieved from http://www.sage-ereference.com

Tacq, J. (2011). Causality in qualitative and quantitative research. Quality \& Quantity, 45(2), 263-291. http://dx.doi.org/10.1007/s11135-009-9293-0

Taneja, S., Taneja, P., \& Gupta, R. (2011). Researches in corporate social responsibility: A review of shifting focus, paradigms, and methodologies. Journal of Business Ethics, 101(3), 343-364. http://dx.doi.org/10.1007/s10551-010-0732-6

Taylor, G., Tower, G., van der Zahn, M., \& Neilson. J. (2008). Corporate governance determinants on Australian resource companies' financial instrument disclosure practices. Asian Review of Accounting, 16(1), 56-73. http://dx.doi.org/10.1108/13217340810872472

Tsamenyi, M., Enninful-Adu, E., \& Onumah, J. (2007). Disclosure and corporate governance in developing countries: Evidence from Ghana. Managerial Auditing Journal, 22(3), 319-319-334. http://dx.doi.org/10.1108/02686900710733170

Yi, A., Davey, H., \& Eggleton, I.R.C. (2011). Towards a comprehensive theoretical 


\section{Macrothink}

Asian Journal of Finance \& Accounting

ISSN 1946-052X 2013, Vol. 5, No. 1

framework for voluntary IC disclosure. Journal of Intellectual Capital, 12 (4), 571 - 585. http://dx.doi.org/10.1108/14691931111181733

Wacker, J. G. (1998). A definition of theory: research guideline for different theory-building research methods in operations management. Journal of Operations Management, 16, 361-385. http://dx.doi.org/10.1016/S0272-6963(98)00019-9

Wacker, J. G. (2008). A conceptual understanding of requirements for theory-building research: Guidelines for scientific theory building. Journal of Supply Chain Management, 44(3), 5-15. http://dx.doi.org/10.1111/j.1745-493X.2008.00062.x

Zahra, S. A., \& Newey, L. R. (2009). Maximizing the impact of organization science: Theory-Building at the intersection of disciplines and/or fields. Journal of Management Studies, 46(6), 1059-1075. http://dx.doi.org/10.1111/j.1467-6486.2009.00848.x

\section{Copyright Disclaimer}

Copyright reserved by the author(s).

This article is an open-access article distributed under the terms and conditions of the Creative Commons Attribution license (http://creativecommons.org/licenses/by/3.0/). 